\title{
Operations manager turnover and inventory fluctuations
}

\author{
José A. Alfaro, Josep A. Tribó* \\ Department of Business Administration, Carlos III University, Calle Madrid 126, 28903 Getafe, Madrid, Spain
}

\begin{abstract}
We argue that a recently appointed operations manager deploys a higher variability inventory policy than a hightenure operations manager does. This contention is supported by the idea that the former manager determines the production schedule by focusing on the current-period demand for information, while the latter also incorporates her expectations over future demand shocks. A second theoretical outcome of this study is that the variability of inventory and of the number of firm's employees are positively correlated, especially in firms with a recently appointed operational manager. Such managers use cojointly inventory and temporary workers to buffer demand shocks more often than high-tenure managers. Empirical support for these propositions was gathered from two databases of Spanish manufacturing firms.
\end{abstract}

Keywords: Operations manager; Turnover; Inventory fluctuations

\section{Introduction}

The determinants of firms' inventory policy have been thoroughly studied in operations management. Models addressing such issue have found that managers hold inventories either to minimize firms' total cost of operations under uncertainty conditions (Blinder and Maccini, 1991) or as a basic element of firms' overall strategy (Rotemberg and Saloner, 1989). A third stream of research has investigated the relationship between layoffs and inventory variations (Haltiwanger and Maccini, 1988, 1994). In particular, these authors analyze how temporary work-

\footnotetext{
*Corresponding author. Dept. Economia de la Empresa, University Carlos III, C/Madrid 126, 28903 Getafe, Madrid, Spain. Tel.: + 34-916249321; fax: +34-916249608.

E-mail addresses: jaalfaro@emp.uc3m.es (J.A. Alfaro), joatribo@emp.uc3m.es (J.A. Tribó).
}

ers can serve as a buffer mechanism, quite similar to inventories, to smooth production.

Our paper departs from previous studies in its focus of analysis, which shifts from the downstream echelons of the chain of command (workers) to the upstream level (operations managers (OMs). A number of papers study the role of OMs, such as Oakland and Sohal (1989) and D'Netto et al. (1998). However, none of such investigations focus on the eventual influence of OMs over the variability of the firm's inventory policy. Specifically, we contend that the tenure of OMs within the firm exerts a lasting influence on the design of inventory policy. We argue that low-tenure OMs act in a short-sighted way, and define an inventory policy which is basically contingent on currentperiod demand shocks. Conversely, high-tenure OMs (not recently appointed) incorporate their expectations over future demand shocks in the way they define the firm's inventory policy. This 
feature, in turn, smoothes the changes in the inventory level.

The second point of the paper draws on Haltiwanger and Maccini (1990). These authors show the existence of a double mechanism to buffer demand shocks: inventories and temporary worker layoffs. Our purpose is to study whether the tenure of an $\mathrm{OM}$ in the firm exerts an influence on the way in which these two mechanisms are used. We argue that low-tenure managers have a short-time perspective that makes them prefer temporary workers (the ones to buffer demand shocks) to permanent ones, as these are more expensive in the short term. Thus, decisions of recently appointed managers about inventory level and the number of employees will show preference to use cojointly both mechanisms to buffer demand shocks more often than high-tenure managers would do.

Empirical evidence that supports these ideas has been gathered from a database of Spanish firms.

This paper consists of three more sections. The second one explains the theoretical arguments. In the third section we conduct the empirical analysis. Lastly, the fourth one outlines our concluding remarks.

\section{Theoretical framework}

The tenure of a manager in the firm influences her decisions. On the one hand, low-tenure managers focus on short-term results in order to prove themselves and convince the owners that their skills are high. On the other hand, a hightenure manager, in principle, bears less pressure to achieve positive short-term results and might be willing to undertake long-term planning. Palley (1997) shows that less stable managers act in a myopic way and select short-term investment projects. Drawing on the same logic, we expect that high-tenure OMs investment decisions on inventories will be less myopic than those of lowtenure OMs. High-tenure OMs, in contrast to recently appointed ones, will design the firm's inventory policy based not only on current demand shocks, but also on their expectations of future demand shocks. As a consequence of that, high-tenure OMs will assess the firm's optimal inventory level more accurately and will attempt to adjust inventories to that level in every period. ${ }^{1}$ The cost of not adjusting to this level is twofold: Small shocks imply higher inventory costs, larger shocks imply higher probability of shortage in the future. A recently appointed OM will behave differently, putting more weight on current demand shocks. Her limited experience within the firm hinders good prediction making on future demand. From that manager's point of view, future shocks will basically be unexpected, and this will generate more inventory volatility. In short:

Hypothesis 1. Firm's inventory variability is lower with a high-tenure $\mathrm{OM}$ than with a recently appointed OM.

A second question, which was addressed by Haltiwanger and Maccini (1990), is the existence of different mechanisms to smooth demand shocks. Temporary worker layoffs for negative demand shocks or temporary worker hiring for positive ones, can be used as a complementary buffer mechanism of inventories as these authors point out. In that case a positive correlation between the variations of both variables is expected.

Hypothesis 2. [Haltiwanger and Maccini] Firms that show a high turnover in their employees also show a higher inventory variability than the average firm of the corresponding sector.

Connected with the previous statement, we can argue over the influence of the tenure of an OM in the way these mechanisms to buffer demand shocks are used. Alfaro and Tribó (2001) show that the short-term focus of low-tenure managers leads them to hire temporary workers instead of permanent ones. The basic argument is that temporary workers are less expensive in the short term since the comparative advantage of the latter is in the long term, linked to increases in their productivity. Low-tenure managers are, however, only interested in the near future. In this situation, if a manager decides the inventory policy and the

\footnotetext{
${ }^{1}$ Stock-adjustment model (Lovell, 1961).
} 
Table 1

Variable definition

CHANINV Equates to $1(0)$ if the variation rate of firm's inventories is higher (lower), in absolute value, than the mean rate of the sector between period $t$ and period $t+1$

CHANGE Equates to $1(0)$ if the OM has (not) changed from period $t-1$ to period $t$

TENURE Equates to 1 if the OM has not been replaced in period $t$, and it will not be replaced in the next period. Also, its value is zero when the $\mathrm{OM}$ has been replaced

CHANGEMP Equates to 1(0) if the variation rate of firm's employees is higher (lower), in absolute value, than the mean rate of the sector between period $t-1$ and $t$

SIZE Equates to $1(0)$ when the number of a firm's employees is higher (lower) than 100

CHANSALES Equates to $1(0)$ if the rate increase of firm's sales is higher (lower) than the mean rate of the sector between period $t-1$ and period $t$

RST This ratio is defined as short-term debt divided by total debt

SECTOR Equates to 1 if the firm belongs to "textile" sectors (SIC 22 and 23), and zero if it belongs to the other sectors FINDIS Equates to 1(0) if the ratio of financial expenses to the EBITDA moves from a value higher than 2 at the beginning of the year to a value lower than 1 at the end

labor policy, the lower her tenure is, the more complementary the labor and inventory policy become. The reason is that the labor-smoothing channel is based on temporary workers (Haltiwanger and Maccini, 1990), precisely those workers whom a low-tenure manager is biased to hire. This defines our last hypothesis to contrast:

Hypothesis 3. Low-tenure OMs use inventories and temporary workers in a more complementary way than high-tenure managers do.

\section{Empirical analysis}

\subsection{Data and variable definition}

We gathered data from two complementary databases to test for our hypotheses. The DUNS 50,000 database provides information on the managerial structure of the 50,000 more important Spanish manufacturing firms. This database, thus, becomes instrumental to determine the turnover of OMs. Unfortunately, Spanish firms are not obliged to report the name of the OM, and this has decreased significantly the number of firms under investigation. The second database, SABE, is the largest database for Spanish firms. It provides accounting and financial information for more than 200,000 firms.
Our study has focused on four sectors: the car industry (SIC 37), machinery (SIC 35), basic textile (SIC 22), and apparel industry (SIC 23). We have chosen them because they are intensive in inventory investments and they are especially relevant for the Spanish economy. ${ }^{2}$ By filtering ${ }^{3}$ and crossreferencing the data in DUNS and SABE, we have obtained an incomplete panel data of 540 firms with 3161 observations for the period 1994-1998. Table 1 summarizes the variables we use in our empirical investigation:

CHANINV pinpoints observations where the relative changes of inventories are significant: higher than the average of the sector. We use this threshold criterion in all variables. We characterize OMs tenure with two variables, which are inversely related: CHANGE and TENURE. We take as high tenure those OM with at least 2 years within the firm and that will not be replaced in the next year. ${ }^{4}$ This is a way to capture some stability in the contract of these managers. On the contrary,

\footnotetext{
${ }^{2}$ Official statistics given by the Spanish Department of Industry (http://www.ine.es/inebase/cgi/um), show that for the year 2000 the combined net sales of these four sectors represented $30 \%$ of the GDP.

${ }^{3}$ We reject firms with non-sense values, such as employment $<0$, internal resources $<0$, debt $<0$, stocks $<0$, financial expenditures $<0$.

${ }^{4}$ More demanding criteria would have reduced the variability of this variable beyond a level that would have prevented to conduct conditional logit estimations.
} 
a low-tenure manager is a recently appointed OM. The characterization of significant variations in employment and sales is made with the CHANGEMP and CHANSALES variables, respectively. We control for size effects with the SIZE variable, where 100 is the threshold value, which separates big and small firms (this is the normal criteria used by Spanish institutions). Variable RST is a measure of the firm's financial constraints, which are quite relevant to shape changes in the firms (Kashyap et al., 1994). This variable complements FINDIS, which accounts for situations of financial distress. ${ }^{5}$ Finally, we use SECTOR as a sector dummy variable.

\subsection{Methods and results}

To test the previous hypotheses we conduct logit estimations ${ }^{6}$ over the dichotomic variable CHANINV that measures the degree of the firm's inventory variability. The panel structure of the data allows controlling for the existence of individual effects, as well as to focus on the variations of each particular firm's inventory level once its $\mathrm{OM}$ has been removed. The econometric specification we adopt is the following:

$$
\begin{aligned}
& \text { CHANINV }_{i t+1} \\
&=\alpha+\beta_{1}\left\{\begin{array}{c}
\text { CHANGE } \\
\text { TENURE }
\end{array}\right\}_{i t}+\beta_{2} \text { CHANGEMP }_{i t} \\
&+\beta_{3} \text { CHANSALES }_{i t}+\beta_{4} \text { SIZE }_{i t+1} \\
&+\beta_{5} \text { RST }_{i t+1}+\beta_{6} \text { SECTOR }_{i t+1} \\
&+\beta_{7} \text { FINDIS }_{i t+1}+\psi_{t+1}+u_{i}+\varepsilon_{i t+1}
\end{aligned}
$$

The variable CHANGE is lagged one period because an OM appointed at the end of period $t$ might begin her activity in period $t+1$ and not in period $t$. As this information is not available, the easy way to avoid this problem is to lag this variable by one period. In order to test Hypothesis 2, we introduce CHANGEMP in the specification

\footnotetext{
${ }^{5}$ We adopt the criterion of Asquith et al. (1994) to define this kind of situations.

${ }^{6} \mathrm{We}$ focus on logit estimations because conditional logit estimation allows controlling for individual effects.
}

with one-period lag as an instrument, because this hypothesis predicts an endogenous relationship between both variables. Finally, some control variables are incorporated. First, CHANSALES accounts for the existence of demand shocks that generate big variations in the firm's sales. This variable is also lagged one period to reduce eventual endogeneity problems. Note that inventories are the residual after production and sales; thus, there is a contemporaneous connection between CHANINV and CHANSALES. The natural instrument to use in these situations is the one-period lagged variable. We also introduce variables, to control for size effects (SIZE), for eventual cash shortages due to the existence of short-term debt (RST), for sectorial effects (SECTOR) and for the existence of situations of financial distress (FINDIS). With this last variable, we try to extract the effect of a reorganization process in a financially distressed firm that could eventually lead to the OM be removed as well as to a liquidation of assets like inventories. Table 2 shows the results of estimating Eq. (1).

The first two columns correspond to simple cross-section logit estimations, whereas column 3 shows the results of the conditional logit estimation. All the estimations comply with the Wald test of overall significativity. However, the most relevant results are those of the conditional logit estimation because the Hausman Test rejects the null hypothesis of non-existence of individual effects $\left(u_{i}=0\right)$ at a $99 \%$ confidence level. Thus, column 3 shows consistent estimates and we take those results as the most relevant. However, we should be aware that the presence of variables with potential endogeneity problems could distort the results, especially in the conditional logit estimations. In that case a strict exogeneity in the independent variables is required. In the next section, we address this issue by conducting a robust analysis with multinomial logit estimations. Additionally, we restrict the conditional logit estimations to the TENURE variable. The reason not to use CHANGE as the main independent variable is that an endogeneity problem with CHANINV may emerge. An owner may replace the OM under those circumstances that also generate a high inventory variation (i.e. organizational 
Table 2

Logit estimation of CHANINV

\begin{tabular}{lccc}
\hline & Cross-section estimation $^{\mathrm{a}}$ & Cross-section estimation $^{\mathrm{a}}$ & Fixed-effect estimation $^{\mathrm{a}}$ \\
\hline CHANGE & $0.592^{* *}(2.012)$ & $-594^{* *}(2.012)$ & $-2.208^{* *}(2.060)$ \\
TENURE & & $0.660^{* * *}(3.254)$ & $0.858^{*}(1.519)$ \\
CHANGEMP & $0.520^{* * *}(2.759)$ & $0.393^{* *}(1.910)$ & $-0.569^{*}(1.782)$ \\
CHANSALES & $0.472^{* * *}(2.445)$ & $-0.507^{* * *}(2.386)$ & $-0.178(0.130)$ \\
SIZE & $-0.508^{* * *}(2.624)$ & $0.334(0.506)$ & $-0.616(0.284)$ \\
RST & $0.543(0.897)$ & $0.623^{* * *}(3.019)$ & $-1.635(1.453)$ \\
SECTOR & $0.582^{* * *}(3.050)$ & $-0.371(0.687)$ & \\
FINDIS & $-0.653(1.228)$ & $-1.267^{* *}(1.924)$ & \\
Constant & $-2.477^{* * *}(4.157)$ & 795 & 231 \\
& & $34.97(0.000)$ & $15.28(0.018)$ \\
Number of observations & 896 & 4.37 & 9.20 \\
Wald Test & $42.91(0.000)$ & & $73.89(0.000)$ \\
Pseudo R2 & 4.47 & & \\
Hausman Test & & & \\
\hline
\end{tabular}

${ }^{a} t$-statistics in parenthesis. Includes time dummy variables. ${ }^{*} 90 \%$ signif. ${ }^{* *} 95 \%$ signif. ${ }^{* * *} 99 \%$ signif.

${ }^{\mathrm{b}}$ This variable is dropped in the conditional logit estimation since there is no within group variability.

restructuring). ${ }^{7}$ With TENURE, the previous problem is less acute since this variable is defined in terms of the number of periods an $\mathrm{OM}$ is in charge of firm inventory policy.

Table 2 shows that the CHANGE variable is both positive and significant, at a $95 \%$ confidence level, whereas the TENURE variable is negative and significant at a $95 \%$ level in both estimations. Thus, consistently with Hypothesis 1, the higher the tenure of an OM, the lower the relative change of the firm's inventory with respect to the average of the sector. Concerning CHANGEMP, the estimation shows that significant changes in the number of employees have a positive impact on the probability of significant changes in the firm's inventories. However, this is only weakly significant $(90 \%)$ in the conditional logit estimation. We are going to precise this outcome in the next section by conducting a robust analysis with multinomial logit estimations.

Our control variables show, first, contradictory results between the normal and the conditional logits estimations for the CHANSALES variable. Potential endogeneity problems may also appear with this variable, and we postpone any definitive conclusion until the next section where we tackle

\footnotetext{
${ }^{7}$ We gratefully acknowledge this comment to one of the referees.
}

these issues. Second, the remaining variables seem not to exert a significant impact on the relative variations of a firm's inventory level.

\subsubsection{Endogeneity problems. Multinomial logit}

In the previous section we have argued that there may be some endogenous relationships between CHANINV and the independent variables CHANGE, CHANGEMP and CHANSALES. To manage this problem, we conduct three different multinomial logit estimations. With the first one, we attempt to compute the conditional probability of CHANINV $=1$ contingent on $\mathrm{CHANGE}=1$, in one case, and $\mathrm{CHANGE}=0$ in the other. The econometric strategy we follow begins with the estimation of the joint probabilities of CHANINV and CHANGE. This is made by conducting a multinomial logit estimation with a dependent variable, $V$, that adopts four values contingent on the different combinations of the latter variables:

0 when $\mathrm{CHANINV}=0$ and $\mathrm{CHANGE}=0$;

1 when $\mathrm{CHANINV}=0$ and $\mathrm{CHANGE}=1$;

2 when $\mathrm{CHANINV}=1$ and $\mathrm{CHANGE}=0$ and 3 when $\mathrm{CHANINV}=1$ and $\mathrm{CHANGE}=1$. 


\begin{tabular}{|c|c|c|c|}
\hline & $\begin{array}{l}\text { Prob }(\text { CHANINV }=1) \\
\text { conditioned to }\end{array}$ & $T$-test ${ }^{\mathrm{b}}$ & $\begin{array}{l}\text { Number of } \\
\text { observations }\end{array}$ \\
\hline $\begin{array}{l}\mathrm{CHANGE}=1 \\
\mathrm{CHANGE}=0\end{array}$ & $\begin{array}{l}24.163 \\
18.484\end{array}$ & $\begin{array}{l}10.785 \\
(0.000)\end{array}$ & 3914 \\
\hline $\begin{array}{l}\text { CHANGEMP }=1 \\
\text { CHANGEMP }=0 \\
\text { CHANSALES }=1 \\
\text { CHANSALES }=0\end{array}$ & $\begin{array}{l}26.228 \\
15.169 \\
28.165 \\
20.238\end{array}$ & $\begin{array}{l}24.899 \\
(0.000) \\
19.321 \\
(0.000)\end{array}$ & $\begin{array}{l}1640 \\
1640\end{array}$ \\
\hline
\end{tabular}

\footnotetext{
${ }^{\mathrm{a}}$ In percentage $(\%)$.

${ }^{\mathrm{b}} T$-test of the mean differences.
}

To be consistent with the univariate logit analysis, the specification adopted takes as independent variables, apart from CHANGE, those others from the univariate specification defined in Eq. (1). As a result, four different joint probabilities are obtained: changes in employees and inventories $(V=3)$, changes in inventories but not in employees $(V=2)$, changes in the number of employees but not in inventories $(V=1)$, and no significant changes in the number of employees, nor in the inventory level $(V=0)$. Finally, we can compute with these joint probabilities, the conditional probabilities of $\mathrm{CHANINV}=1$ conditioned on $\mathrm{CHANGE}=1$ in one case, or on $\mathrm{CHANGE}=0$ in the other. ${ }^{8}$ It is important to note that estimating the joint probability takes care of the possible endogeneity problems of the two variables. This makes the comparison of the conditional probabilities a reliable measure of the impact of CHANGE in the variation of firm's inventory once possible endogeneity problems are controlled for. An equivalent strategy is used for the analysis of CHANINV and CHANGEMP in the second multinomial logit estimation and similarly for CHANINV and CHANSALES in the third one. The formal procedure is just to substitute the CHANGE variable in all the previous arguments by CHANGEMP in the former case, and by

\footnotetext{
${ }^{8} \operatorname{Prob}(\mathrm{CHANINV}=1 / \mathrm{CHANGE}=1)$

$=\operatorname{Prob}(V=3) /[\operatorname{Prob}(V=3)+\operatorname{Prob}(V=1)]$

$\operatorname{Prob}(\mathrm{CHANINV}=1 / \mathrm{CHANGE}=0)$

$=\operatorname{Prob}(V=2) /[\operatorname{Prob}(V=2)+\operatorname{Prob}(V=0)]$
}

CHANSALES in the latter. The results obtained are reported in Table 4.

Table 3 shows three different results. First, the probability to find a significant variation rate of firm's inventories is higher $(99 \%)$ when a recently appointed $\mathrm{OM}$ is in charge. This confirms in a more robust way Hypothesis 1. Second, there is a significantly $(99 \%)$ superior probability to find a firm's inventory variation rate higher than the average of the sector in those firms that exhibit a significant change in the number of their employees. This result concurs with Haltiwanger and Maccini's contention. Finally, a higher inventory variation is obtained after a period of a significant sales increase.

To address Hypothesis 3, we pursue the same strategy as that described in the previous multinomial logit estimation concerning CHANINV and CHANGEMP variables but the four joint probabilities $\{W=0, W=1, W=2, W=3\}^{9}$ are computed contingent on the TENURE variable. In so doing we are able to compare, for hightenure and low-tenure OMs, the conditional probability of a significant inventory variation rate $(\mathrm{CHANINV}=1)$ conditioned on the existence of a significant employee variation rate $(\mathrm{CHAN}$ GEMP = 1) (Table 4).

\footnotetext{
${ }^{9} W=0$ when $\mathrm{CHANINV}=0$ and $\mathrm{CHANGEMP}=0 ; W=1$ when $\mathrm{CHANINV}=0$ and $\mathrm{CHANGEMP}=1 ; W=2$ when $\mathrm{CHANINV}=1$ and $\mathrm{CHANGEMP}=0$ and $W=3$ when $\mathrm{CHANINV}=1$ and $\mathrm{CHANGEMP}=1$.
} 


\begin{tabular}{|c|c|c|c|c|}
\hline & $\begin{array}{l}\text { TENURE }=1 \\
\text { Prob. }(\mathrm{CHAINV}=1) \\
\text { conditioned to }^{\mathrm{a}}\end{array}$ & $\begin{array}{l}\text { TENURE }=0 \\
\text { Prob. }(\text { CHAINV }=1) \\
\text { conditioned to }{ }^{\mathrm{a}}\end{array}$ & $T$-test of means ${ }^{\mathrm{b}}$ & $\begin{array}{l}\text { Number of } \\
\text { observations }\end{array}$ \\
\hline $\mathrm{CHANGEMP}=0$ & 15.631 & 9.856 & $5.249(0.000)$ & \\
\hline$T$-test of means ${ }^{\mathrm{b}}$ & $21.555(0.000)$ & $23.610(0.000)$ & & \\
\hline Number of observations & 1474 & 166 & & \\
\hline
\end{tabular}

${ }^{\mathrm{a}}$ In percentage $(\%)$.

${ }^{\mathrm{b}} T$-test of the mean differences.

Interestingly enough, we obtain that a lowtenure OM buffers demand shocks making use of both mechanisms (inventories and workers) in a more complementary way than a high-tenure OM does. Note that the probability to find a significant inventory variation rate conditional on a significant employees variation rate is superior (at a $99 \%$ confidence level) in case that a low-tenure $\mathrm{OM}$ is in charge than when a high-tenure $\mathrm{OM}$ is $(39.115 \%$ versus $24.654 \%$ ). This result is reversed when there has not been a significant variation rate in the number of employees $(\mathrm{CHANGEMP}=0)$. In this situation the previous conditional probability is higher for the case of a high-tenure OM. As a synthesis, the impact of employee variation rate on the probability of finding an inventory variation rate higher than the average of the sector is superior for low-tenure OMs than for high-tenure ones. We report, for completeness, the correlation between dichotomic variables, CHANINV and CHANGEMP $\}: 27.91 \%$ for low-tenure OM, and $8.67 \%$ for high-tenure OM. Thus, a low-tenure OM uses both mechanisms (inventories and temporary employees) as complementary channels to accommodate to demand shocks, while a hightenure OM uses them more independently. This conforms to Hypothesis 3.

\section{Concluding remarks}

In this paper we have shown that the tenure of $\mathrm{OMs}$ is a relevant characteristic to determine a firm's inventory variability as well as the connec- tion between this variability and that of the number of employees. We have argued that a recently appointed OM takes decisions focusing on a shorter temporal horizon than a high-tenure OM does, because the former has to comply with some short-term objectives to ensure her continuity within the firm. This feature generates, among other things, that low-tenure managers put the weight to define the firm's inventory policy mainly on current-period demand shocks, a feature that hinders a possible inter-temporal smoothing of the effects of demand shocks. This lack of perspective by this $\mathrm{OM}$ generates a higher inventory variability in comparison with that defined by hightenure OM. A second result draws on the work of Haltiwanger and Maccini (1990), regarding the existence of a positive correlation between the firm's inventory variability and that of the firm's employee number. We argue that this should be especially observed in firms with a low-tenure OM.

Our empirical test is based on a sample of Spanish manufacturing firms. It supports for our theoretical assertions. First, firms with a hightenure OM show lower inventory variability than those others with a recently appointed OM. Second, firms reporting high employee variation rate also show higher inventory variability than the average firm in their industry. Third, firms with a recently appointed $\mathrm{OM}$, use inventories and worker layoffs in a more complementary way than firms with a high-tenure OM, that use both mechanisms more independently.

Our results suggest some further lines where work should be done. First, to investigate the 
influence of $\mathrm{OM}$ contract characteristics, other than the length, in the definition of the firm's inventory policy. We believe that the bonus of the $\mathrm{OM}$ compensation scheme is also relevant to explain the firm's inventory changes. Second, the use of more precise indicators of inventory variations should be pursued in order to check the robustness of our results. Third, a dynamic extension of the model (e.g., by considering contract renegotiation) might help in a further understanding of the firms' inventory policy.

\section{Acknowledgements}

The authors wish to thank to Salvador Carmona, Begoña García, María José Álvarez and two anonymous referees of this journal for their many helpful suggestions on earlier drafts of this paper. Financial support provided by the project PB970185-C03-01 is gratefully acknowledged. All the errors are our own responsibility.

\section{References}

Alfaro, J.A., Tribó, J.A., 2001. Managerial and worker turnover WP 01-13 (04). Universidad Carlos III. https:// docubib.uc3m.es/WORKINGPAPERS/WB/wb011304.pdf.

Asquith, P., Gertner, R., Scharfstein, D., 1994. Anatomy of financial distress: an examination of junk-based issues. Quarterly Journal of Economics 109, 625-658.
Blinder, A.S., Maccini, L.J., 1991. Taking stock: A critical assessment of recent research on inventories. Journal of Economic Perspectives 5 (1), 73-96.

D’Netto, B., Sohal, A., Trevyllyan, J., 1998. An empirical assessment of the production/operations manager's job. Production and Inventory Management Journal 39 (1), $57-60$.

Haltiwanger, J.C., Maccini, L.J., 1988. A model of inventory and layoff behavior under uncertainty. The Economic Journal 39 (2), 731-745.

Haltiwanger, J.C., Maccini, L.J., 1990. The dynamic interaction of inventories, temporary and permanent layoffs. Working Paper 238. Johns Hopkins University, Baltimore, MD.

Haltiwanger, J.C., Maccini, L.J., 1994. Inventories and multiperiod labor contracts: Implications for business cycle analysis. In: Brunner, K., Meltzer, A. (Eds.), Inventory Cycle and Monetary Policy. Springer, New York, pp. 175-205.

Kashyap, A.K., Lamont, O.A., Stein, J.C., 1994. Credit conditions and the cyclical behavior of inventories. Quarterly Journal of Economics 109 (3), 565-592.

Lovell, M.C., 1961. Manufacturer's inventories, sales expectations, and the acceleration principle. Econometrica 29, 293-314

Oakland, J.S., Sohal, A., 1989. The education, training and career of production managers in British industry. International Journal of Operations and Production Management 9 (8), 63-90.

Palley, T., 1997. Managerial turnover and the theory of shorttermism. Journal of Economic Behavior and Organization 32, 547-557.

Rotemberg, J., Saloner, G., 1989. The cyclical behavior of strategic inventories. Quarterly Journal of Economics 104 (1), 73-97. 